\title{
Short communication: Interactions of milk, fat, and protein yield genotypes with herd feeding characteristics
}

\author{
M. W. Dekleva, ${ }^{*}$ C. D. Dechow, ${ }^{* 1}$ J. M. Daubert, ${ }^{*}$ W. S. Liu, ${ }^{*}$ G. A. Varga, ${ }^{*}$ S. Bauck, $\dagger$ and B. W. Woodward $\dagger$ \\ *Department of Dairy and Animal Science, The Pennsylvania State University, University Park 16802 \\ †Merial Ltd., Duluth, GA 30096
}

\section{ABSTRACT}

Data from 879 Holstein cows from 11 tie-stall herds in Pennsylvania were analyzed to determine the effects of nutritional management practices on the level of genetic expression for milk, fat, and protein yields. Environments were defined according to the amount of dry matter refusals at the end of $24 \mathrm{~h}$ for the average cow (DMR), diet crude protein percentage $(\mathrm{CP})$, and diet $\mathrm{NE}_{\mathrm{L}}$ concentration. Sire predicted transmitting ability (PTA) was available for all cows, whereas 775 cows were genotyped and received a molecular breeding value (MBV) for milk, fat, and protein yields. Milk, fat, and protein yields were regressed on sire PTA and cow MBV independently in addition to combined breeding values $(\mathrm{CBV})$ of sire PTA and cow MBV. Four-trait animal models with fat-corrected milk yield in high and low environments plus either body weight or body condition score in high and low environments treated as separate traits were also evaluated. Regressions on sire PTA ( 0.31 for fat yield to 0.54 for milk yield) were significantly lower in the 5 herds that had the lowest average DMR than in the 6 herds with highest average DMR (0.82 for fat yield to 1.11 for protein yield). The regressions of milk and protein yield on CBV were also significantly lower in the 5 herds with low $\mathrm{NE}_{\mathrm{L}}$ concentration in the ration than in herds that had high $\mathrm{NE}_{\mathrm{L}}$ concentration. Genetic correlations from animal models showed that large cows were more affected by low $\mathrm{DMR}, \mathrm{CP}$, and $\mathrm{NE}_{\mathrm{L}}$ concentration than smaller cows. Efforts to minimize feed wastage must ensure that cows receive adequate nutrient intake to avoid suppression of genetic potential for yield, particularly for larger cows. Key words: genotype $\times$ environment interaction, selection, nutrition

Received July 22, 2011.

Accepted November 14, 2011.

${ }^{1}$ Corresponding author: cdechow@psu.edu

\section{Short Communication}

Characterizations of genotype $\times$ environment interaction $(\mathbf{G} \times \mathbf{E})$ depend on the identification of advantageous and disadvantageous environments for expression of a trait. Most $\mathrm{G} \times \mathrm{E}$ studies have focused on national boundaries (Fikse et al., 2003; Zwald et al., 2003), regional characteristics (Weigel et al., 1999), or general herd characteristics, as measured by production traits such as peak milk yield (Fikse et al., 2003). Considerations of feeding management have generally been limited to describing herds as grazing or confinement (Weigel et al., 1999).

The objectives of this study were to collect herd data related to feed availability and dietary composition, and to estimate interactions of genotype with herd feed management characteristics.

Feed intake, BCS, BW, milk yield, fat yield, and protein yield were obtained for 879 cows in 11 commercial Pennsylvania tie-stall herds that were sired by 299 bulls with an official genetic evaluation. Details regarding the method of measuring 24-h feed intake were previously reported by Vallimont et al. (2010). Briefly, each herd was visited once per month during the week of 6 consecutive milk recording tests, and feed samples were taken to determine diet composition and DM percentage. Herd managers were instructed to deliver an equal amount of feed to all cows, and any subsequent feed redistribution among cows was performed by researchers. The amount of feed delivered to each cow (and thus DMI) was an estimate based on total feed cart weight and the number of cows fed from the feed cart. Spot checks were performed for individual cows from each cart and additionally for any cow that appeared visually to have more or less feed than other cows in the string, which was often the first or last cow fed from a cart. Researchers weighed the total amount of feed left for each cow the following morning to determine dry matter refusals (DMR). The amount of feed delivered to each cow was an estimate, but feed left in front of each cow was precisely measured.

Table 1 reports 305-d standardized lactation averages of FCM, milk yield (MY), fat yield (FY), and protein 
Table 1. Number of cows in the analysis (n), 305-d standardized lactation averages of FCM, milk yield (MY), fat yield (FY), protein yield (PY), and test-day averages for dry matter refusals (DMR), dietary $\mathrm{CP}$, energy density of the diet $\left(\mathrm{NE}_{\mathrm{L}}\right), \mathrm{BW}$, and BCS, by herd

\begin{tabular}{|c|c|c|c|c|c|c|c|c|c|c|}
\hline Herd & $\mathrm{n}$ & $\begin{array}{l}\text { FCM, } \\
\text { kg }\end{array}$ & $\begin{array}{c}\mathrm{MY}, \\
\mathrm{kg}\end{array}$ & $\begin{array}{l}\mathrm{FY} \\
\mathrm{kg}\end{array}$ & $\begin{array}{l}\text { PY, } \\
\mathrm{kg}\end{array}$ & $\begin{array}{l}\text { DMR, } \\
\text { kg }\end{array}$ & $\begin{array}{c}\mathrm{CP} \\
\%\end{array}$ & $\begin{array}{c}\mathrm{NE}_{\mathrm{L}}, \\
\mathrm{Mcal} / \mathrm{kg}\end{array}$ & $\begin{array}{l}\text { BW, } \\
\text { kg }\end{array}$ & BCS \\
\hline 1 & 84 & $11,917.9$ & $11,580.9$ & 394.2 & 335.5 & 1.54 & 16.4 & 1.67 & 660.2 & 3.04 \\
\hline 4 & 33 & $8,927.3$ & $9,813.2$ & 372.1 & 304.3 & 2.35 & 15.6 & 1.67 & 669.4 & 3.24 \\
\hline 5 & 58 & $8,078.2$ & $8,345.0$ & 317.6 & 250.8 & 1.10 & 18.1 & 1.58 & 627.5 & 2.85 \\
\hline 6 & 165 & $9,271.8$ & $10,174.1$ & 347.1 & 301.7 & 1.62 & 16.0 & 1.66 & 671.5 & 3.04 \\
\hline 9 & 70 & $10,622.5$ & $9,324.5$ & 430.4 & 330.8 & 1.50 & 17.2 & 1.68 & 678.5 & 3.34 \\
\hline 10 & 96 & $10,524.1$ & $11,280.9$ & 420.5 & 339.0 & 0.97 & 17.9 & 1.68 & 633.5 & 3.10 \\
\hline 11 & 65 & $8,879.3$ & $8,865.9$ & 358.5 & 262.2 & 0.61 & 14.4 & 1.63 & 623.0 & 2.98 \\
\hline Average & 80 & $9,559.5$ & $9,859.3$ & 370.3 & 301.8 & 1.40 & 16.6 & 1.65 & 655.7 & 3.18 \\
\hline
\end{tabular}

yield (PY). Average test-day DMR, diet CP percentage, energy density of the diet $\left(\mathrm{NE}_{\mathrm{L}}\right), \mathrm{BW}$, and BCS are also reported. The herds were split into high and low management groups for $\mathrm{DMR}, \mathrm{CP}$, and $\mathrm{NE}_{\mathrm{L}}$. Six herds $(1,3,4,6,8$, and 9$)$ had average DMR of at least 1.5 $\mathrm{kg}$ per cow and formed the high DMR group, whereas 5 herds with average $\mathrm{CP}$ of $16.9 \%$ or more $(5,7,8,9$, 10) formed the high CP management group. The division in herd-average $\mathrm{NE}_{\mathrm{L}}$ was less clear, so herds were divided such that the high (herds 1, 3, 4, 7, 9, and 10) and low management categories had an approximately equal number of cows.

Sire PTA for milk (PTAM), fat (PTAF), and protein (PTAP) yields were available for all cows. DNA was extracted from blood using Qiagen DNeasy-96 kits (Qiagen, Valencia, CA) for 775 cows (sired by 278 bulls) and genotyped for a panel of 121 candidate gene markers (Igenity, Merial Ltd., Duluth, GA) with Sequenom iPlex MassArray (Sequenom Inc., San Diego, CA). The marker panel contains causative mutations for QTL associated with milk yield and composition (as well as intake and body energy traits), including DGAT1 (Grisart et al., 2002), GHR (Blott et al., 2003; Banos et al., 2008), and $A B C G^{2}$ (Cohen-Zinder et al., 2005), and other markers selected based on prior evidence of association with traits of economic significance. Cows were assigned a molecular breeding value (MBV) for milk (MBVM), fat (MBVF), and protein (MBVP) yield based on the Igenity profile for dairy cattle. The Igenity profile was developed by genotyping a large population of dairy bulls followed by single marker association analyses using the bulls' PTA as computed by USDA. Briefly, markers identified as individually significant or approaching significance at $P<0.10$ were subsequently evaluated for linkage disequilibrium with all of the other selected markers. Only one of any pair of markers in high linkage disequilibrium was then used as a candidate for the final panel for a specific trait. The MBV for a trait is computed using a compound covariate prediction equation, the allele substitution effects, and genotypes for a specific individual, where the genotypes coded as 0,1 , or 2 are the weights for each marker (Tukey, 1993).

A third measure of genetic potential was created that combined sire PTA and MBV (CBV) as follows:

$$
\mathrm{CBV}_{\mathrm{T}}=\text { sire } \mathrm{PTA}_{\mathrm{T}}+\left[\mathrm{w}_{\mathrm{T}} \times\left(\mathrm{MBV}_{\mathrm{T}}-\text { sire } \mathrm{PTA}_{\mathrm{T}}\right)\right] \text {, }
$$

where ${ }_{\mathrm{T}}=$ trait (milk, fat, or protein yield) and $\mathrm{w}=$ a weighting factor of 0.35 for milk yield, 0.45 for fat yield, and 0.30 for protein yield. A cow's MBV reflects the genetic contribution of both sire and dam. The residual MBV obtained after subtracting sire PTA leaves a measure of the dam genetic contribution plus the sire Mendelian sampling effect. The residual MBV effect is based on a low-density marker panel and is expected to have lower reliability than sire PTA from progeny testing or from a genomic evaluation that relies on a dense marker panel, so should receive less weight in the CBV than sire PTA. The weight applied to the residual MBV component began at 0 and was increased in 0.05 increments to 0.50 , with $\mathrm{w}_{\mathrm{T}}$ selected that maximized the $F$-statistic for regression on $\mathrm{CBV}$ as described below.

Milk, fat, and protein yields were regressed on their respective sire PTA, MBV, and CBV in ASREML (Gilmour et al., 2006). Records from all lactations completed before the start of feed intake collection were included in the analysis, resulting in 1,950 records of milk, fat, and protein yield (1,698 for MBV and CBV). Milk, fat, or protein yield in high and low management groups were treated as separate traits with the following model:

$$
Y_{i j k l}=L_{a c t}+\beta_{i j} \times G E N+P E_{i k}+H C C_{i l}+\varepsilon_{i j k l},
$$

where $Y_{i j k l}=305-\mathrm{d}$ milk, fat, or protein yield in herd environment $i$ ( $i=$ high or low management group); Lact 
$=$ the fixed effect of lactation $j$ for trait $i ; \beta=$ the fixed coefficient of regression for trait $i$ on sire PTA, MBV, or $\mathrm{CBV} ; G E N=$ sire PTA, MBV, or CBV corresponding to trait $i ; P E=$ the random permanent environment effect of cow $k$ for trait $i$; $H C C=$ the fixed effect of herd-calving-cluster $l$ for trait $i$ (Vallimont et al., $2010)$; and $\varepsilon_{i j k l}=$ random error. Statistical differences of regression coefficients in high or low environments were determined according to the method of Paternoster et al. (1998).

Data were also analyzed using 4-trait animal models to estimate heritabilities and genetic correlations among $4 \% \mathrm{FCM}, \mathrm{BW}$, and BCS in alternate environments. In contrast to the regression models, which considered only records from cows that had feed intake available at some point, FCM from 857 herdmates that were contemporaries during earlier lactations were included to avoid bias because second and later lactation cows represented a selected group of cows. This resulted in 3,569 total FCM records.

Two 4-trait animal models that contained FCM in high and low environments treated as the first 2 traits and either BW or BCS in high and low environments treated as the second traits were evaluated as follows:

$$
Y_{i j k l}=\text { Lact }_{i j}+\text { Animal }_{i k}+P E_{i k}+H C C_{i l}+\varepsilon_{i j k l},
$$

where $Y_{i j k l}=305-\mathrm{d}$ FCM in high and low herd environment plus either BW or BCS in high and low herd environment; $L a c t=$ fixed effect of lactation $j$ for trait $i$; Animal $=$ random effect of animal $k$ for trait $i ; P E$ $=$ random permanent environmental effect of cow $k$ for trait $i ; H C C=$ fixed effect of herd-calving-cluster $l$ for trait $i$; and $\varepsilon_{i j k l}=$ random error.

Average $\mathrm{DMR}, \mathrm{CP}$, and $\mathrm{NE}_{\mathrm{L}}$ were considered the primary indicators of feeding management for this study instead of intake levels. A part-whole relationship exists between genetic potential for yield and intake level because of a positive genetic correlation between yield and intake (Veerkamp, 1998; Vallimont et al., 2010). Herds with higher yield may have higher intake because their cows are genetically inclined to eat more, rather than a management decision to feed cows at a higher level. Average DMR and diet nutrient content are therefore more direct indicators of feeding management independent of cow genotype.

The average daily DMR across herds was $1.40 \mathrm{~kg}$ and varied between 0.61 and $2.35 \mathrm{~kg}$ (Table 1). Average DMR was directly associated with the proportion of cows that had no feed refusals, which ranged from $0 \%$ of cows in herd 4 to $26 \%$ of cows in herd 10, and averaged $11 \%$ across all herds. Ranking herds by the percentage of cows with no refusals yielded an exact inverse of the ranking by level of DMR.

Levels of inclusion in the diet of $\mathrm{CP}$ and $\mathrm{NE}_{\mathrm{L}}$ were derived from nutrient analysis and can also be directly compared across herds. Crude protein averaged 16.6\% across herds, and ranged from 14.4 to $18.1 \%$. Net energy of lactation averaged $1.65 \mathrm{Mcal} / \mathrm{kg}$, with a range from 1.58 to $1.70 \mathrm{Mcal} / \mathrm{kg}$.

Regression coefficients for PTAM, PTAF, and PTAP (Table 2) when herds were split by DMR were close to 1 in herds with a high level of DMR, indicating that response to selection did not deviate from expectation. In herds with a low level of DMR and a high proportion of cows with no feed remaining after a 24-h feeding period, regression coefficients were $0.54,0.31$, and 0.38 for PTAM, PTAF, and PTAP, respectively. The coefficients $<1.0$ indicated that response to selection was less than predicted based on sire genetic evaluations in those herds. The regression coefficients were significantly different between high and low DMR herds for PTAF and PTAP, and a trend toward significance $(P$ $<0.10)$ was observed for PTAM.

Regressions of milk, fat, and protein yields on MBV (Table 3) were positive in both herd environments, but did not follow the same pattern as the PTA regressions and were associated with larger standard errors. Regression coefficients for CBV were numerically higher for all traits in the high DMR herds, with regression on CBV for protein yield significantly different (Table 4). The regressions on sire PTA and CBV indicate that

Table 2. Coefficients of regression (with SE) of 305-d milk, fat, and protein yield on sire PTA of milk (PTAM), fat (PTAF), and protein (PTAP) in high and low management groups

\begin{tabular}{llcccccc}
\hline $\begin{array}{l}\text { Management } \\
\text { factor }\end{array}$ & Group & PTAM & SE & PTAF & SE & PTAP & SE \\
\hline $\mathrm{DMR},{ }^{1} \mathrm{~kg}$ & High & $1.00 \dagger$ & 0.18 & $0.82^{*}$ & 0.17 & $1.11^{*}$ & 0.18 \\
$\mathrm{CP}, \%$ & Low & $0.54 \dagger$ & 0.19 & $0.31^{*}$ & 0.18 & $0.38^{*}$ & 0.18 \\
& High & 1.00 & 0.21 & 0.73 & 0.22 & 0.84 & 0.22 \\
$\mathrm{NE}_{\mathrm{L}}, \mathrm{Mcal} / \mathrm{kg}$ & Low & 0.69 & 0.16 & 0.58 & 0.15 & 0.80 & 0.16 \\
& High & $1.05 \dagger$ & 0.20 & 0.71 & 0.18 & $1.08 \dagger$ & 0.19 \\
& Low & $0.60 \dagger$ & 0.16 & 0.53 & 0.16 & $0.58 \dagger$ & 0.17 \\
\hline
\end{tabular}

${ }^{1} \mathrm{DMR}=$ dry matter refusal.

*High and low groups differ at $P<0.05$; †high and low groups differ at $P<0.10$. 
Table 3. Coefficients of regression (with SE) of 305-d milk, fat, and protein yields on molecular breeding values for milk (MBVM), fat (MBVF), and protein (MBVP) in high and low management groups

\begin{tabular}{llccccrc}
\hline $\begin{array}{l}\text { Management } \\
\text { factor }\end{array}$ & Group & MBVM & SE & MBVF & SE & MBVP & SE \\
\hline $\mathrm{DMR}^{1}{ }^{1} \mathrm{~kg}$ & High & 0.42 & 0.33 & 0.57 & 0.29 & 0.33 & 0.44 \\
& Low & 0.46 & 0.31 & 0.66 & 0.31 & 0.44 & 0.43 \\
$\mathrm{CP}, \%$ & High & 0.54 & 0.39 & $-0.02^{*}$ & 0.37 & 0.53 & 0.54 \\
& Low & 0.39 & 0.29 & $0.95^{*}$ & 0.26 & 0.29 & 0.39 \\
$\mathrm{NE}_{\mathrm{L}}, \mathrm{Mcal} / \mathrm{kg}$ & High & 0.70 & 0.34 & 0.53 & 0.28 & 0.66 & 0.45 \\
& Low & 0.25 & 0.30 & 0.85 & 0.32 & -0.02 & 0.43 \\
\hline
\end{tabular}

${ }^{1} \mathrm{DMR}=$ dry matter refusal.

*High and low groups differ at $P<0.05$.

underfeeding is limiting the yield potential of cows in herds with low DMR. Low regression coefficients indicate that sire reranking is also possible in these herds (Weigel et al., 1999).

Regression coefficients were generally not significantly different when herds were stratified by CP. The exception was regressions of fat yield on MBVF. A 1-kg increase in MBVF corresponded to $0.02 \mathrm{~kg}$ less fat in the high CP group compared with a response of $0.95 \mathrm{~kg}$ in the low CP group. Whether this represents a true G $\times \mathrm{E}$ interaction or is due to sampling error is not clear; however, results were in the opposite direction and not significantly different in high or low $\mathrm{CP}$ groups when regressing on sire PTAF. It should be noted that all but 2 of the low herds (4 and 11) were well within generally recommended ranges for $\mathrm{CP}$.

Regression on CBV for milk and protein yield were both significantly higher in herds with high diet $\mathrm{NE}_{\mathrm{L}}$ concentrations, whereas regression on PTAM and PTAP trended toward significance $(P<0.10)$. The high $\mathrm{NE}_{\mathrm{L}}$ group also had a numerically greater response to selection for milk and protein yield in the MBV models, but results were not significant.

One element of this work was to investigate the relationship between estimates of genotype derived from a marker panel containing a smaller number of causative mutations versus that derived from a traditional quantitative measure of genetic merit such as PTA, and to investigate whether those 2 measures could be combined to improve the prediction. The amount of variation accounted for by the panel was expected to be somewhat less than would be seen in a PTA or from a larger SNP panel. This was reflected in weights applied to MBV that were less than $50 \%$ when constructing CBV. The largest weight (45\%) was applied to MBVF, which may reflect the relatively large influence of DGAT1 on fat production compared with milk and protein (Grisart et al., 2002).

Regressions on MBV were positive in almost all instances, suggesting that genetic merit can be predicted with marker panels that contain known causative mutations; nevertheless, the larger standard deviations and lower level of significance associated with regression on MBV likely reflect the reduced amount of variation explained by the marker panel when compared with PTA. The potential of using combinations of PTA and MBV was demonstrated by the higher level of significance when herds were stratified by $\mathrm{NE}_{\mathrm{L}}$. Regression on PTA and MBV were not significantly different for high and low groups, but results were significant for regression on CBVM and CBVP.

Heritability estimates (not shown) for FCM were higher in herds that had high DMR (0.26), high CP (0.37), and high $\mathrm{NE}_{\mathrm{L}}$ concentration (0.36) than in the corresponding low environments (range 0.16 to 0.22 ). This suggests greater genetic variation and a larger

Table 4. Coefficients of regression (with SE) of 305-d milk, fat, and protein yields on combined PTA and molecular breeding values for milk (CBVM), fat (CBVF), and protein yield (CBVP)

\begin{tabular}{llcccccc}
\hline $\begin{array}{l}\text { Management } \\
\text { factor }\end{array}$ & Group & CBVM & SE & CBVF & SE & CBVP & SE \\
\hline $\mathrm{DMR},{ }^{1} \mathrm{~kg}$ & High & 1.52 & 0.27 & 1.33 & 0.28 & $1.63^{*}$ & 0.27 \\
$\mathrm{CP}, \%$ & Low & 0.92 & 0.29 & 0.71 & 0.30 & $0.58^{*}$ & 0.28 \\
& High & 1.45 & 0.32 & 0.84 & 0.37 & 1.20 & 0.34 \\
$\mathrm{NE}_{\mathrm{L}}, \mathrm{Mcal} / \mathrm{kg}$ & Low & 1.17 & 0.25 & 1.20 & 0.25 & 1.21 & 0.24 \\
& High & $1.80^{*}$ & 0.31 & 1.20 & 0.29 & $1.65^{*}$ & 0.28 \\
& Low & $0.84^{*}$ & 0.25 & 0.97 & 0.28 & $0.78^{*}$ & 0.26 \\
\hline
\end{tabular}

${ }^{1} \mathrm{DMR}=$ dry matter refusal.

*High and low groups differ at $P<0.05$. 
Table 5. Genetic correlations $\left(\mathrm{r}_{\mathrm{a}}\right)$ and standard errors of FCM with BW and with BCS in high and low management groups

\begin{tabular}{llrrrc}
\hline $\begin{array}{l}\text { Management } \\
\text { factor }\end{array}$ & Group & $\mathrm{r}_{\mathrm{a}}$ BW & SE BW & $\mathrm{r}_{\mathrm{a}}$ BCS & SE BCS \\
\hline $\mathrm{DMR},{ }^{1} \mathrm{~kg}$ & High & -0.01 & 0.15 & -0.21 & 0.19 \\
$\mathrm{CP}, \%$ & Low & -0.80 & 0.20 & -0.63 & 0.24 \\
& High & 0.02 & 0.16 & -0.13 & 0.20 \\
$\mathrm{NE}_{\mathrm{L}}, \mathrm{Mcal} / \mathrm{kg}$ & Low & -0.56 & 0.18 & -0.32 & 0.27 \\
& High & -0.05 & 0.15 & -0.21 & 0.21 \\
& Low & -0.54 & 0.20 & -0.43 & 0.26 \\
\hline
\end{tabular}

${ }^{1} \mathrm{DMR}=$ dry matter refusals.

response to selection in such herds, which is in general agreement with the results obtained for regression of yield on sire PTA. Genetic correlations between FCM in high and low environments were $0.26 \pm 0.28$ for $\mathrm{NE}_{\mathrm{L}}, 0.61 \pm 0.29$ for DMR, and $0.66 \pm 0.29$ for CP. The genetic correlation for FCM in high and low $\mathrm{NE}_{\mathrm{L}}$ groups was not significantly different from 0 and was significantly less than 1 , which suggests that significant reranking of sires may occur in response to diet energy concentration. The genetic correlations for DMR or CP herd groupings were not significantly different from 1 due to the large standard errors, but were small enough to suggest the potential for $\mathrm{G} \times \mathrm{E}$ interactions.

Genetic correlation estimates of FCM with BW and BCS are reported in Table 5. Correlations between milk yield and live weight have been previously reported to be slightly negative, ranging from -0.09 to -0.14 (Veerkamp and Brotherstone, 1997; Toshniwal et al., 2008). Correlations in the current study were similar to values previously reported in the groups associated with high levels of DMR (-0.01), CP (0.02), and $\mathrm{NE}_{\mathrm{L}}$ $(-0.05)$. However, correlations were more negative than previously reported in groups with low levels of DMR $(-0.80), \mathrm{CP}(-0.56)$, and $\mathrm{NE}_{\mathrm{L}}(-0.54)$. Genetic correlations between FCM and BCS were also strongly negative (Table 5), with the more-negative correlations associated with herds that had low DMR, $\mathrm{CP}$, and $\mathrm{NE}_{\mathrm{L}}$. This result suggests that cows genetically inclined to direct nutrients toward increasing BCS and BW were particularly affected by low levels of nutrition.

Nutritional management factors affecting nutrient intake are associated with $\mathrm{G} \times \mathrm{E}$ interactions. In particular, offering less feed than cows were capable of consuming or providing a diet with low energy concentration did not allow cows to fully express their production potential. A $\mathrm{G} \times \mathrm{E}$ interaction was created under restricted feeding, with the genetic potential of larger cows being more severely limited than the genetic potential of smaller cows.

\section{ACKNOWLEDGMENTS}

Igenity is a registered trademark of Merial Ltd. (Duluth, GA). All other marks are property of their respective owners. This research was supported by CSREES-2008-34437-19335 and genotyping was provided by Igenity. The authors gratefully acknowledge the generosity of the 11 farms that participated in the trial. Andrew F. Read and Andrew S. Bell (Department of Biology, Penn State, University Park) are acknowledged for sharing their equipment. The assistance of Kelly Crawford (Huck Institutes, Penn State, University Park) is also greatly appreciated.

\section{REFERENCES}

Banos, G., J. A. Woolliams, B. W. Woodward, A. B. Forbes, and M. P. Coffey. 2008. Impact of single nucleotide polymorphisms in leptin, leptin receptor, growth hormone receptor, and diacylglycerol acyltransferase (DGAT1) gene loci on milk production, feed, and body energy traits of UK dairy cows. J. Dairy Sci. 91:3190-3200.

Blott, S., J. J. Kim, S. Moisio, A. Schmidt-Küntzel, A. Cornet, P. Berzi, N. Cambisano, C. Ford, B. Grisart, D. Johnson, L. Karim, P. Simon, R. Snell, R. Spelman, J. Wong, J. Vilkki, M. Georges, F. Farnir, and W. Coppieters. 2003. Molecular dissection of a quantitative trait locus: A phenylalanine-to-tyrosine substitution in the transmembrane domain of the bovine growth hormone receptor is associated with a major effect on milk yield and composition. Genetics 163:253-266.

Cohen-Zinder, M., E. Seroussi, D. M. Larkin, J. J. Loor, A. Everts-van der Wind, J. H. Lee, J. K. Drackley, M. R. Band, A. G. Hernandez, M. Shani, H. A. Lewin, J. I. Weller, and M. Ron. 2005. Identification of a missense mutation in the bovine ABCG2 gene with a major effect on the QTL on chromosome 6 affecting milk yield and composition in Holstein cattle. Genome Res. 15:936-944.

Fikse, W. F., R. Rekaya, and K. A. Weigel. 2003. Genotype $\times$ environment interaction for milk production in Guernsey cattle. J. Dairy Sci. 86:1821-1827.

Gilmour, A. R., B. J. Gogel, B. R. Cullis, S. J. Welham, and R. Thompson. 2006. AS-REML User Guide. Release 2.0. VSN International Ltd., Hemel Hempstead, UK.

Grisart, B., W. Coppieters, F. Farnir, L. Karim, C. Ford, P. Berzi, N. Cambisano, M. Mni, S. Reid, P. Simon, R. Spelman, M. Georges, and R. Snell. 2002. Positional candidate cloning of a QTL in dairy cattle: Identification of a missense mutation in the bovine DGAT1 gene with a major effect on milk yield and composition. Genome Res. 12:222-231. 
Paternoster, R., R. Brame, P. Mazerolle, and A. Piquero. 1998. Using the correct statistical test for the equality of regression coefficients. Criminology 36:859-866.

Toshniwal, J. K., C. D. Dechow, B. G. Cassel, J. A. D. R. N. Appuhamy, and G. A. Varga. 2008. Heritability of electronically recorded daily body weight and correlations with yield, dry matter intake, and body condition score. J. Dairy Sci. 91:3201-3210.

Tukey, J. W. 1993. Tightening the clinical trial. Control. Clin. Trials $14: 266-285$

Vallimont, J. E., C. D. Dechow, J. M. Daubert, M. W. Dekleva, J. W. Blum, C. M. Barlieb, W. Liu, G. A. Varga, A. J. Heinrichs, and C. R. Baumrucker. 2010. Genetic parameters of feed intake, production, body weight, body condition score, and selected type traits of Holstein cows in commercial tie-stall barns. J. Dairy Sci. 93:4892-4901.
Veerkamp, R. F. 1998. Selection for economic efficiency of dairy cattle using information on live weight and feed intake: A review. J. Dairy Sci. 81:1109-1119.

Veerkamp, R. F., and S. Brotherstone. 1997. Genetic correlations between linear type traits, food intake, live weight and condition score in Holstein Friesian dairy cattle. J. Anim. Sci. 64:385-392.

Weigel, K. A., T. Kriegel, and A. L. Pohlman. 1999. Genetic analysis of dairy cattle production traits in a management intensive rotational grazing environment. J. Dairy Sci. 82:191-195.

Zwald, N. R., K. A. Weigel, W. F. Fikse, and R. Rekaya. 2003. Application of a multiple-trait herd cluster model for genetic evaluation of dairy sires from seventeen countries. J. Dairy Sci. 86:376-382. 